\title{
Notes on some rare and interesting Cladocera (Crustacea: Branchiopoda: Anomopoda: Chydoridae) from Deepor Beel, Assam, India
}

\author{
B.K. Sharma ${ }^{1} \&$ Sumita Sharma ${ }^{2}$ \\ ${ }^{1,2}$ Freshwater Biology Laboratory, Department of Zoology, North-Eastern Hill University, Permanent Campus, Shillong, \\ Meghalaya 793022, India \\ Email: ${ }^{1}$ profbksharma@gmail.com (corresponding author), ${ }^{2}$ sumitasharma.nehu@gmail.com
}

\begin{abstract}
Plankton samples collected from Deepor Beel, a Ramsar site of India, during August 2008-July 2010, revealed six rare and interesting Cladocera belonging to four genera of the family Chydoridae. The globally important elements include the Australasian Disperalona caudata; the Asian Kurzia (Rostrokurzia) brevilabris; the Indo-Malayan Alona macronyx; and Leydigiopsis curvirostris which is known to occur elsewhere in North and South America. Kurzia (Rostrokurzia) brevilabris is a new record from India while Alona guttata tuberculata, $A$. macronyx and Coronatella anodonta are new records from Assam. The documented species are briefly diagnosed and comments are made on their distribution.
\end{abstract}

Keywords: Cladocera, India, Interesting species, Ramsar site.

Deepor Beel $\left(91^{0} 35^{\prime}-91^{0} 43^{\prime} \mathrm{E} \& 26^{0} 05^{\prime}-26^{0} 11^{\prime} \mathrm{N}\right.$; $40 \mathrm{~km}^{2}$; altitude $42 \mathrm{~m}$ ), an important floodplain lake of the Brahmaputra River basin of northeastern India as well as a Ramsar site, merits considerable significance for its biodiversity value (Sharma \& Sharma 2008). Realizing this importance, the authors undertook

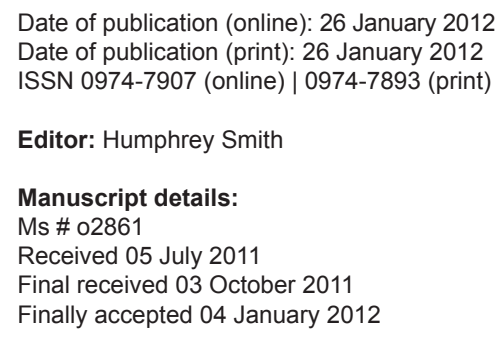

Citation: B.K. Sharma \& Sumita Sharma (2012). Notes on some rare and interesting Cladocera (Crustacea: Branchiopoda: Anomopoda: Chydoridae) from Deepor Beel, Assam, India. Journal of Threatened Taxa 4(1): 2304-2309.

Copyright: (C) B.K. Sharma \& Sumita Sharma 2012. Creative Commons Attribution 3.0 Unported License. JoTT allows unrestricted use of this article in any medium for non-profit purposes, reproduction and distribution by providing adequate credit to the authors and the source of publication.

Acknowledgements: This study is a part of the Ministry of Environment \& Forests (Govt. of India) sponsored project No. 22018-09/2010-CS (Tax) sanctioned to the senior author. The senior author is also thankful to Head, Department of Zoology, North-Eastern Hill University, Shillong for necessary facilities. We wish to thank our reviewers for their valuable comments and suggestions.

\section{OPEN ACGESS | FREE DOWNLOAD}

detailed limnological reconnaissance (August 2008-July 2010) with special reference to faunal diversity and ecology of invertebrates in general and zooplankton diversity in particular. As a part of our study on Cladocera fauna of this interesting wetland, we came across six rare and interesting Cladocera of the family Chydoridae, including four globally important elements namely Disperalona caudata, Kurzia (Rostrokurzia) brevilabris, Alona macronyx and Leydigiopsis curvirostris. In addition, one species is a new record from India and two species are new records from Assam state. All the recorded species are identified with comments on their distribution.

\section{Materials and Methods}

Qualitative plankton samples were collected monthly by towing nylobolt plankton net (No. 25) and were preserved in $5 \%$ formalin. The plankton samples were screened for sorting out different species which were mounted individually in a polyvinyl alcohollactophenol mixture. Different species were identified following Smirnov $(1971,1996)$ and Sharma \& Sharma (2007, 2008). Photographs were taken with a Leica DM 1000 image analyzer. The voucher specimens are deposited in the holdings of the Freshwater Biology Laboratory, Department of Zoology, North-Eastern Hill University, Shillong.

\section{Systematic list of the recorded species \\ Superclass: Crustacea \\ Class: Branchiopoda \\ Superorder: Cladocera (sensu strictu) \\ Order: Anomopoda \\ Family: Chydoridae \\ Subfamily: Chydorinae \\ 1. Disperalona caudata Smirnov, 1996}


Subfamily: Aloninae

1. Alona guttata tuberculata (Kurz, 1875)

2. A. macronyx (Daday, 1898)**

3. Coronatella anodonta (Daday, 1905)**

4. Kurzia (Rostrokurzia) brevilabris Rajapaksa \& Fernando, 1986*

5. Leydigiopsis curvirostris Sars, 1901

* New record from India; ${ }^{* *}$ New record from Assam

\section{Taxonomic notes}

\section{Disperalona caudata Smirnov, 1996 (Images 1-2)}

Characters: Valves longitudinally striated; posterior dorsal angle expressed and posterior ventral angle rounded. Rostrum long, pointed and ventrally directed. Head shield with two main head pores and two small pores between them. Antennule reaching half-way to the tip of rostrum. Postabdomen relatively elongated, with a distinct dorso-distal corner and preanal angle not distinct. Postabdomen with 14 anal teeth, proximal teeth small. Claw with two basal spines; second basal spine smaller than the diameter of the base of claw.

\section{Alona guttata tuberculata (Kurz, 1875)}

Characters: Head shield and valves with characteristic rounded pits. Labral plate rounded. Postabdomen with 8-10 anal spines; pre-anal corner projecting; distal dorsal end projecting beyond base of claws. Claw with a basal spine and with setae on its concave margin.

Distribution: Meghalaya.

\section{Coronatella anodonta (Daday, 1905) (Images 3-4)}

Characters: Body oval, with maximum height in middle. Head shield and valves with distinct tubercles; postero-dorsal and postero-ventral corners of valves rounded. Antennules almost reaching apex of rostrum. Ocellus situated halfway between eye and apex of rostrum. Labral plate rounded, without any denticle on its anterior margin. Postabdomen with anal denticles and lateral setae. Claw with a basal spine.

Distribution: Meghalaya and Rajasthan (?).

\section{Alona macronyx (Daday, 1898) (Images 5-6)}

Characters: Body oval, with maximum height before its middle. Valves with lines and dots; posterodorsal and postero-ventral corners rounded; ventral margin slightly concave. Antennules not reaching apex of rostrum. Ocellus smaller than eye and situated near to it. Labral plate with convex anterior margin and truncate apex. Postabdomen narrowing distally and with an incision at the base of the claws; with 12-14 large marginal anal denticles, distal margin of post-abdomen with a small denticle. Claw with a basal spine nearly half as long as claw.

Distribution: Meghalaya and Madhya Pradesh.

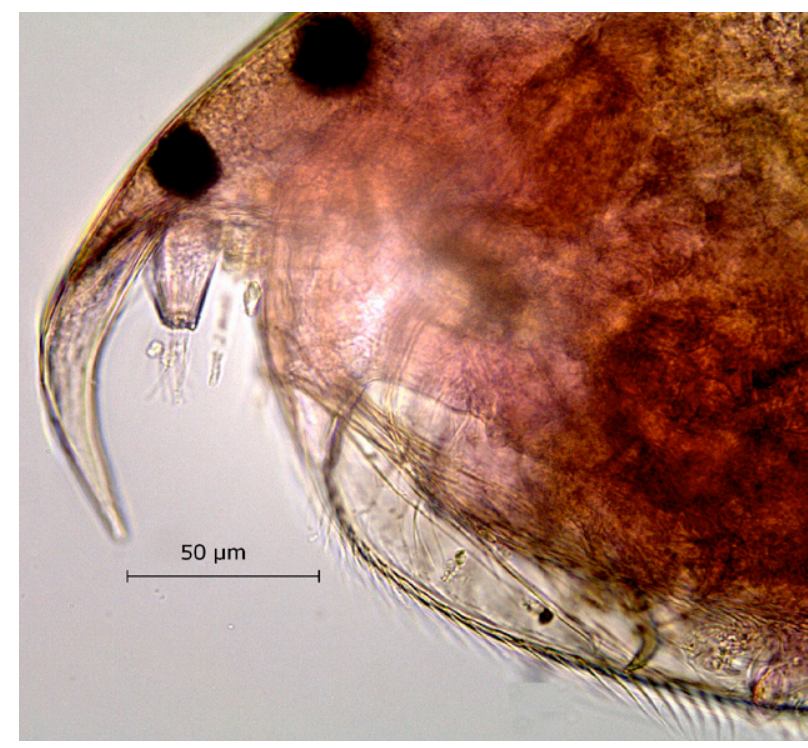

Image 1. Disperalona caudata Smirnov, anterior part of parthenogenetic female

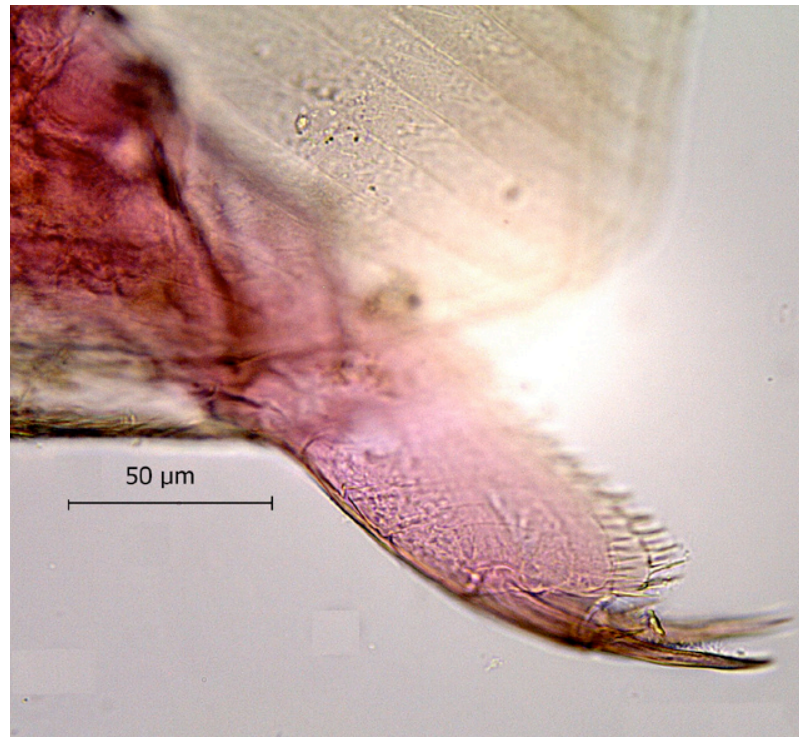

Image 2. D. caudata Smirnov, postabdomen of parthenogenetic female 


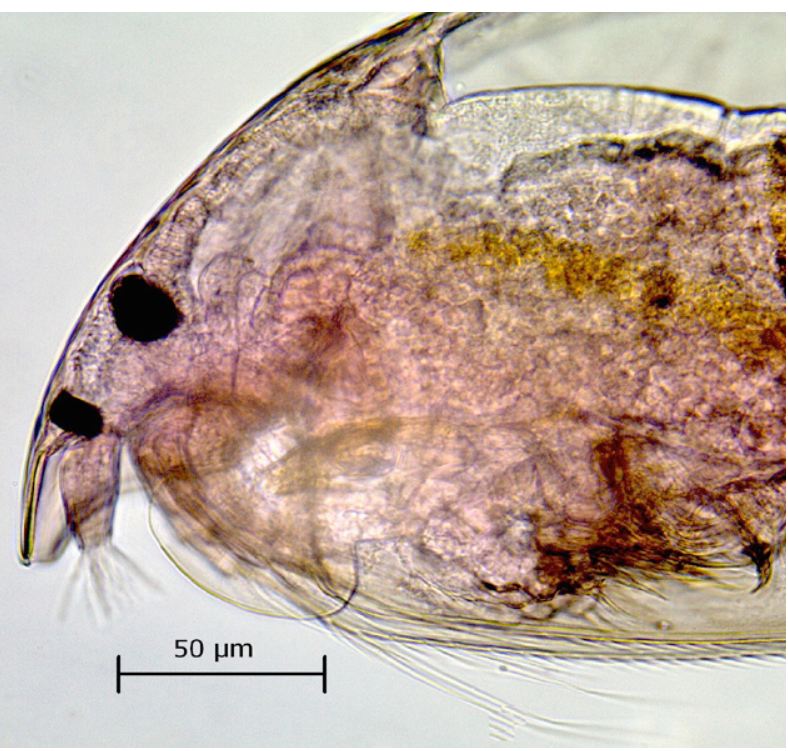

Image 3. Coronatella anodonta (Daday), anterior part of parthenogenetic female

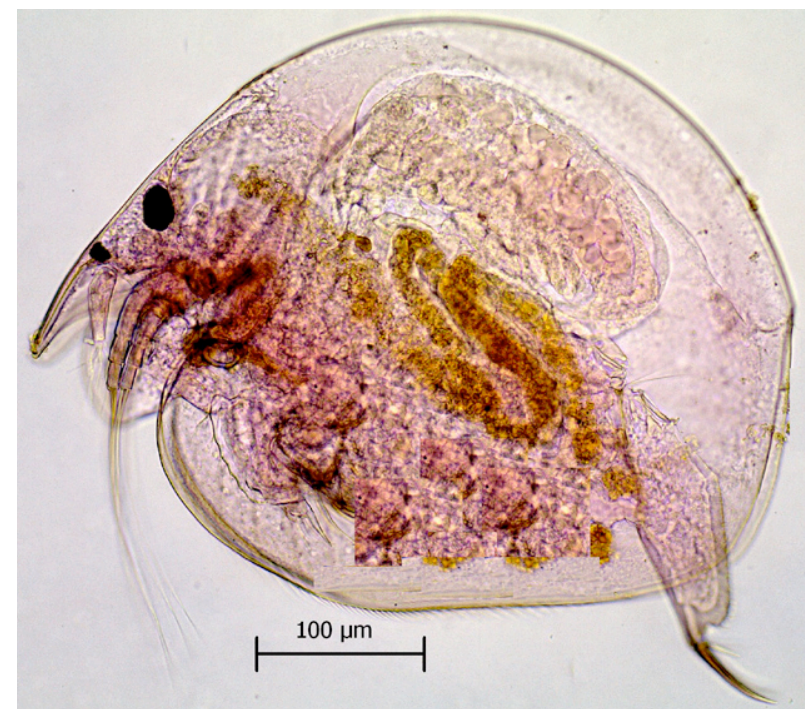

Image 5. Alona macronyx (Daday), anterior part of parthenogenetic female

\section{Kurzia (Rostrokurzia) brevilabris Rajapaksa \& Fernando, 1986 (Images 7-8)}

Characters: Body oval and compressed; posteroventral corner of valves rounded. Valves marked with longitudinal lines; marginal setules along posterolateral corner and sub-marginal setules on posterior margin subequal. Rostrum elongated. Ocellus about half the size of eye and situated close to it. Three connected head pores; medial pore relatively smaller; lateral pores minute. Antennules elongated; only three longest aesthetasces reaching tip of rostrum. Labrum

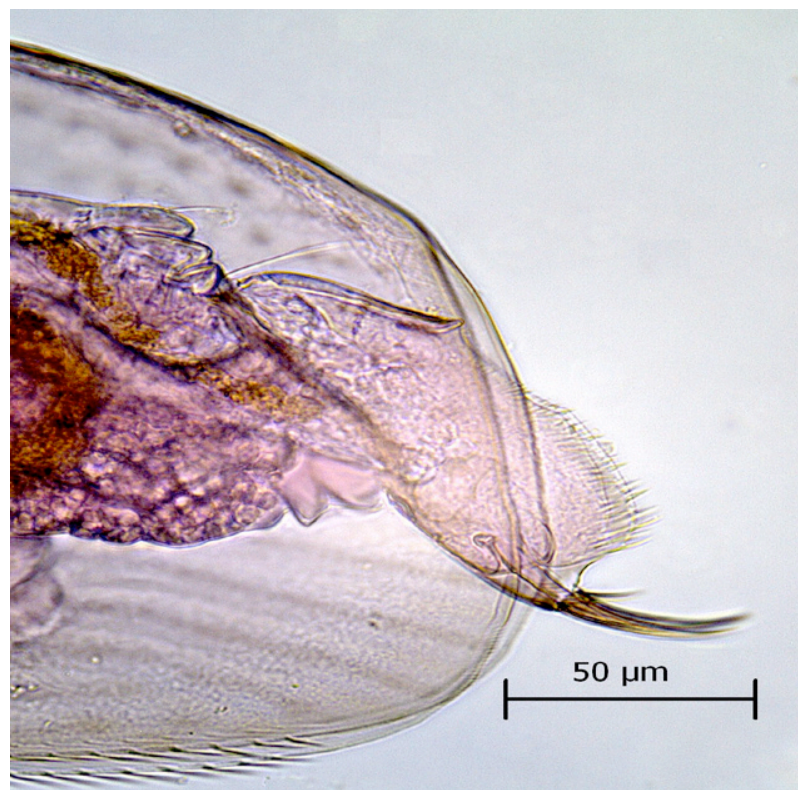

Image 4. Coronatella anodonta (Daday), postabdomen of parthenogenetic female

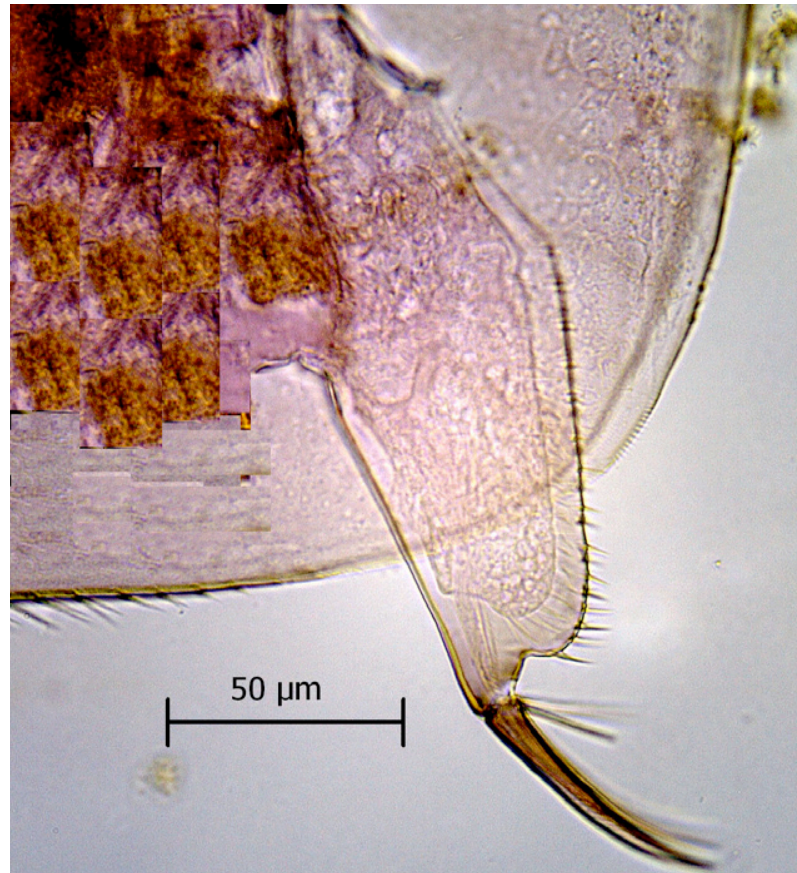

Image 6. A. macronyx (Daday), postabdomen of parthenogenetic female

strongly reduced; labral plate with rounded anterior margin. Post-abdomen elongate; distal corner with a narrow lobe projecting beyond claw; dorsal margin slightly recurved with 10-14 short denticles followed by $3-5$ groups of minute spines. Claw elongated, with setules; basal spine short and with setules at its base. 


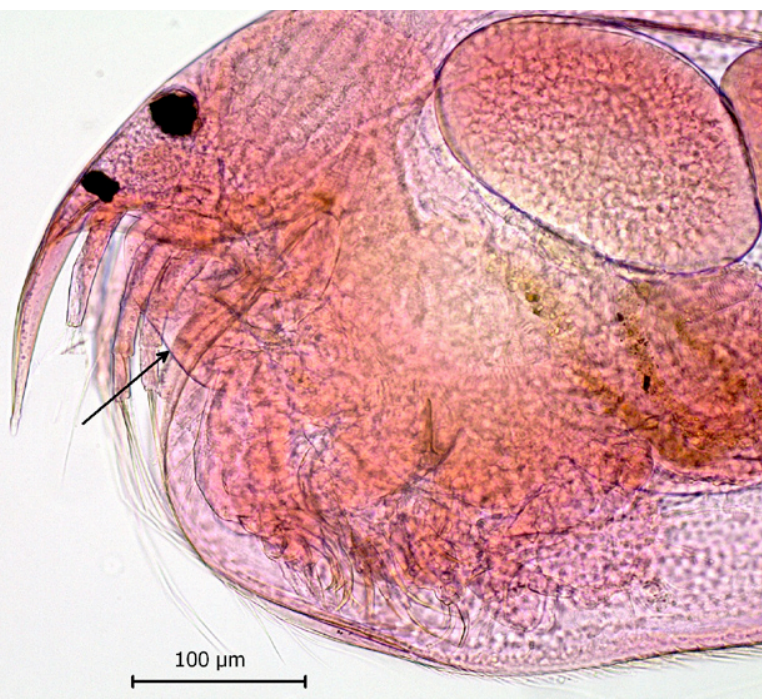

Image 7. Kurzia (Rostrokurzia) brevilabris Rajapaksa \& Fernando, anterior part of parthenogenetic female

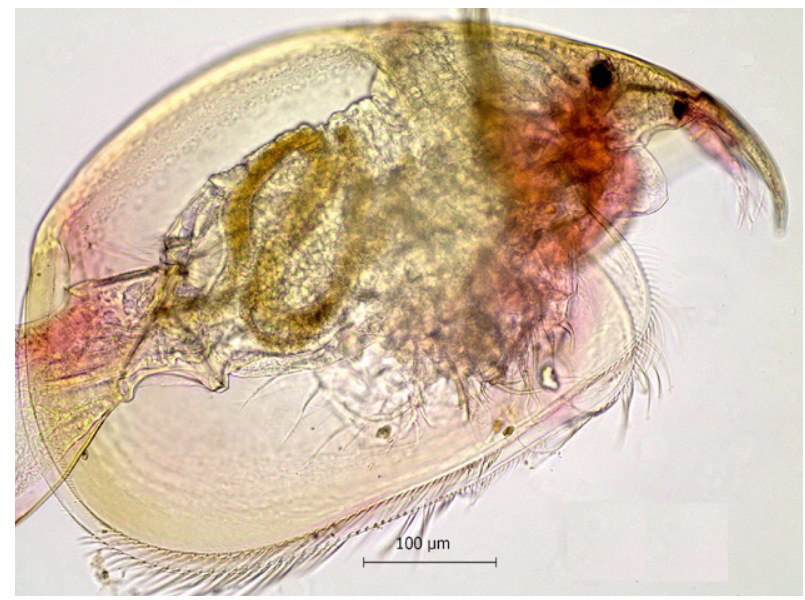

Image 9. Leydigiopsis curvirostris Sars, parthenogenetic female

\section{Leydigiopsis curvirostris Sars, 1901 (Images 9-10)}

Characters: Body with maximum height in the middle. Postero-dorsal and postero-ventral corner of valves rounded. Ventral margin of valves protruded before the middle; entire ventral margin with concentric rows of dots and with setae which continue along posterior margin in a row of fine hairs. Rostrum very long and curved posteriorly. Distance from apex of rostrum to apex of antennule nearly twice the length of antennule. Head-shield with two broadly connected main head pores and two small pores close to them. Plate of labrum triangular and with slightly pointed apex. Ocellus about as large as the eye. Postabdomen large; its dorsal margin distinctly convex and distal

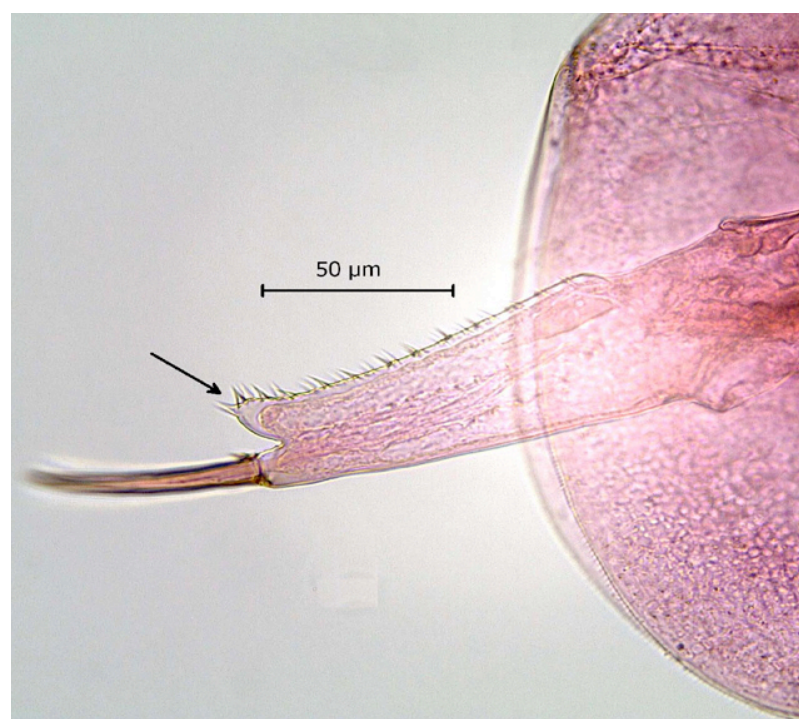

Image 8. K. (Rostrokurzia) brevilabris Rajapaksa \& Fernando, postabdomen of parthenogenetic female

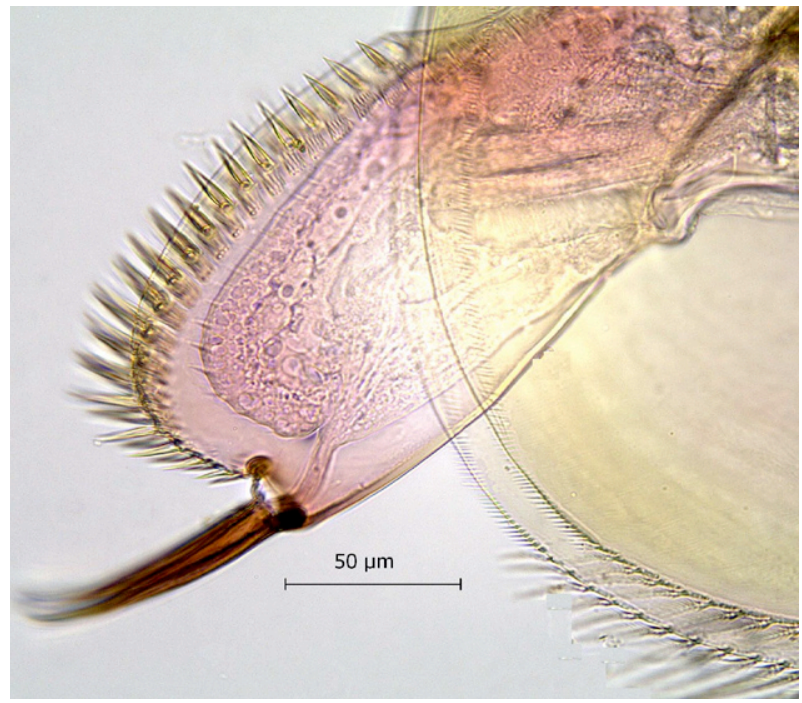

Image 10. L. curvirostris Sars, anterior part of parthenogenetic female

to the anus; distal end of postabdomen rounded. Preanal corner distinct with double row of 16-20 anal denticles, decreasing in size proximally and a row of lateral spinules on each side. Claw large, with setae on the concave margin and with a small basal denticle.

\section{Remarks}

Six species of rare and interesting chydorid Cladocera are reported from Deepor Beel. These include four globally interesting elements viz., the Australasian Disperalona caudata, the Asian Kurzia (Rostrokurzia) brevilabris and the Indo-Malayan 
Alona macronyx, while Leydigiopsis curvirostris is known elsewhere only from Brazil and Nicaragua.

Kurzia (Rostrokurzia) brevilabris is an interesting addition to the Indian Cladocera. Originally described from Thailand (Rajapaksa \& Fernando 1986), this species is also known from Sri Lanka and Philippines. Our present report from northeastern India, therefore, merits biogeographic importance for extension of its range within the South Asian region. Hudec (2000) dealt with five known Kurzia spp. and proposed their subgeneric differentiation into Kurzia sensu strictu and Rostrokurzia. K. (Rostrokurzia) brevilabris is a member of the latter. This sub (tropical) Asian species can be distinctly differentiated from other members of this genus by its diagnostic reduced labrum.

Disperalona caudata, another globally important species, was described from Mudginberri Lagoon, Kakadu National Park, Australia (Smirnov 1996). Sanoamuang (1998) reported it from northeastern Thailand as its first record from Asia. Sharma \& Sharma (2007) reported D. caudata from two floodplain lakes (Deepor and Raidong beels) of the Brahmaputra River basin, Assam extending its distributional range to the Indian subcontinent. This Australasian species depicts an interesting link between the cladoceran fauna of northeastern India, Southeast Asia and Australia. Further, it is known from India, to date, from the state of Assam only.

Leydigiopsis, a very rare genus, was described from Brazil by Sars (1901) and until the end of $20^{\text {th }}$ century, it was presumed to be distributed in South and Central America only (Sinev 2004). In addition, Sanoamuang (1998) examined its single specimen from Kalasin province of northeastern Thailand but could not ascertain species status. Sinev (2004) categorized this genus to be insufficiently studied and remarked on the unclear status of Asian Leydigiopsis. Sharma \& Sharma (2007) extended its distributional range to the Indian subcontinent based on an earlier report of L. curvirostris in Deepor Beel. The present study re-affirms its occurrence, restricted to the Assam State only. We believe that disjunct occurrence of this chydorid of North American origin in India may represent an example of its introduction by man and thus deserves further analysis.

The Indo-Malayan Alona macronyx is a new record from Assam. The first Indian report of this species referred to Indialona jabalpurensis, a new species described from Madhya Pradesh by Rane (1983), which was considered as a synonym of $A$. macronyx (refer Rajapaksa \& Fernando 1987; Sharma \& Sharma 1990). This species was recorded for the first time from northeastern India from Meghalaya (Sharma 2008), and our report further extends its distribution to the adjoining state of Assam. Alona guttata tuberculata and Coronatella anodonta are new records from Assam; the latter is recently observed from the Nokrek Biosphere Reserve of Meghalaya (Sharma \& Sharma 2011) while Sharma (2008) reported the former again from Meghalaya. These two taxa are, hence, known to date only from the northeastern region of India

\section{REFERENCES}

Hudec, I. (2000). Subgeneric differentiation within Kurzia (Crustacea: Anomopoda: Chydoridae) and a new species from Central America. Hydrobiologia 421: 165-178.

Rajapaksa, R. \& C.H. Fernando (1986). Tropical species of Kurzia (Crustacea, Cladocera) with a description of Kurzia brevilabris sp. nov. Canadian Journal of Zoology 64: $250-260$.

Rajapaksa, R. \& C.H. Fernando (1987). A note on Alona macronyx Daday, 1898 (Crustacea, Cladocera). Canadian Journal of Zoology 65: 216-218.

Rane, P. (1983). A new species of Cladocera of genus Indialona Petkovski, 1966 (Family Chydoridae) from India. Journal of the Bombay Natural History Society 80: 194-195.

Sanoamuang, L. (1998). Contributions to the knowledge of the Cladocera of north-east Thailand. Hydrobiologia 362: 45-53.

Sars, G.O. (1901). Contributions to the knowledge of the freshwater Entomostraca of South America, as shown by artificial hatching from dried material. 1. Cladocera. Archiv fur Mathematik og Naturvidenskab Christiana 23(3): 1-102.

Sharma, B.K. \& S. Sharma (1990). On the taxonomic status of some cladoceran taxa (Crustacea: Cladocera) from Central India. Revue Hydrobiologie Tropicale 23: 105-133.

Sharma, B.K. \& S. Sharma (2007). New records of two interesting chydorid cladocerans (Branchiopoda: Cladocera: Chydoridae) from the floodplain lakes of Assam, India. Zoo's Print Journal 22(8): 2799-2801.

Sharma, B. K. \& S. Sharma (2008). Faunal diversity of Cladocera (Crustacea: Branchiopoda) of Deepor beel, Assam (Northeast India) - A Ramsar site. Journal of the Bombay Natural History Society 105(2): 196-201.

Sharma, B. K. \& S. Sharma (2011). Faunal diversity of Cladocera (Crustacea: Branchiopoda) of Nokrek Biosphere Reserve, Meghalaya, Northeast India. Journal of Threatened Taxa 3(10): 2120-2127.

Sharma, S. (2008). Notes on some rare and interesting 
Cladocerans (Crustacea: Branchiopoda) from Meghalaya. Records of the Zoological Survey of India 108(2): 111122.

Sharma, S. \& B.K. Sharma (2008). Zooplankton diversity in floodplain lakes of Assam. Records of the Zoological Survey of India, Occasional Paper No. 290: 1-307.

Sinev, A.Y. (2004). Redescription of two species of the genus Leydigiopsis Sars, 1901 (Branchiopoda, Anomopoda, Chydoridae). Invertebrate Zoology 1(1): 75-92.
Smirnov, N.N. (1971). The World Chydorid Fauna (in Russian). USSR Academy of Sciences, Zoological Institute Nova series 101, 539pp. (Leningrad)

Smirnov, N.N. (1996). Cladocera: The Chydorinae and Sayciinae (Chydoridae) of the World, pp. 1-197. In: Dumont, H.J. \& T. Nogrady (eds.). Guides to Identification of the Microinvertebrates of the Continental Waters of the World: 11. SPB Academic Publishing bv. Amsterdam, The Netherlands. 